\title{
СТРУКТУРНО-СЕМІОТИЧНІ АСПЕКТИ ОНТОЛОГІї МИСТЕЦТВА
}

\begin{abstract}
Д.А. Брус
Поява нових відкриттів у сфері мистецтва потребує грунтовного теоретичного переосмислення феномену мистецтва в рамках сучасної художньої практики. Безперечно, одним з важливих методів дослідження феноменів художньої культури $є$ структурно-семіотичний аналіз мистецтва, що дозволяє проникнути всередину творіння, виділити його структуру, основні елементи та деталі. На сьогодні стає зрозумілим, що з філософсько-естетичної точки зору структуралізм здійснив вагомий прорив в європейську культуру ХХ століття. Однак, оскільки протягом довгого часу структурно-семіотичні методи дослідження художніх творів піддавались нищівній критиці і лише нещодавно відродився інтерес до таких розробок, досі залишається спірним питання щодо їх позитивних методологічних можливостей.

Через велике розмаїття думок з приводу місця і ролі структурносеміотичного методу в онтології мистецтва вважаємо за доцільне звернутись до класичних робіт Р. Барта [1], Б. Ейхенбаума [5], Ю. Лотмана [2], Ц. Тодорова [3], В.Шкловського [4], концепції яких мають виключне значення для нашого дослідження. Загальнотеоретичні проблеми структуралізму висвітлено в працях В. Бичкова, Ю. Борєва, Ю. Степанова, де частково прояснено межі та можливості структурного аналізу. Сучасний аналіз структурно-семіотичного підходу в працях О. Волкової, І. Ільїна, Г. Косікова, І. Скоропанової здійснюється в контексті ситуації постмодерну. Такий підхід підкреслює актуальність структурного підходу, а також надає можливість застосування теоретичних розробок структуралістів для аналізу конкретних художніх творів. Водночас, оскільки багато наукових проблем, пов'язаних зі співвідноше-
\end{abstract}

Актуальні проблеми духовності

(Відп. ред.: Я.В. Шрамко)

Кривий Ріг (2007), 271-279 
нням структуралізму та формалізму, змісту та форми в межах цих доктрин досі залишаються недостатньо дослідженими, є всі підстави в даній статті приділити увагу детальному аналізу структуралістської теорії та її зв'язку із формалізмом та семіотикою. Крім того, ставиться завдання здійснити аналіз основоположних принципів структурно-семіотичної теорії та визначити їх місце в онтології мистецтва.

Як відомо, витоки структуралізму пов'язані з дослідженнями формальної школи, в межах якої сформувався формальний метод дослідження літературних творів. Виникнувши в кінці XIX століття в рамках російської «академічної школи», формальна школа висунула на перший план проблему типологічного вивчення літератури. Саме у теоретичних дослідженнях формалістів загострюється питання вивчення тексту, форми, а також спостерігається відхід від психологічного методу інтерпретації художніх творів, характерний для класичної традиції. Формальний метод привернув до себе увагу завдяки своєму принциповому ставленню до мистецтва як автономної структури. Відродження поетики мало вигляд не простого відтворення окремої часткової проблеми, а стосувалось всієї області наук про мистецтво. Дана концепція, що склала теоретико-методологічне підгрунтя структуралізму, сформувалась на основі визначення мистецтва як поетичної мови.

Розпочавши з дослідження поетичного мистецтва, формалісти надалі почали застосовувати методи, відібрані для вивчення літератури, до інших видів мистецтва. Представники «Спілки вивчення поетичної мови» - Б. Ейхенбаум, Ю. Тинянов, В.Шкловський та інші, висунувши на перший план лінгвістичний аспект художньої творчості, вперше представили структурний опис тексту, зосередившись на його функціонально-технічній стороні. Разом з цим вони вступили в боротьбу за поетику із символістами з метою, звільнивши ії̈ від зв'язку з суб'єктивізмом, повернути поетику на шлях конкретно-наукового дослідження фактів. Звідси - відмова від суб'єктивізму, психологічних та біографічних тлумачень твору, розрив з ідеологічними теоріями мистецтва.

Розвинувшись із гострого інтересу до літератури, формалізм на початковій стадії свого розвитку обмежив коло досліджуваного матеріалу вивченням того, що є даним у творі. Даність художнього твору це основний висхідний початок для формалістів, які задались питанням не про методи вивчення літератури, а про літературу як предмет вивчення. Теоретичні дослідження, на їх думку, мають грунтуватись на вивченні конкретного матеріалу в його специфічних особливостях. Розбудовуючи особливу науку про літературу, формалісти допускали можливість розвитку різноманітних методів в її межах, однак, при 
цьому в центрі уваги мала залишатись специфічність досліджуваного матеріалу.

Потрібно зазначити, що притаманна даному напряму назва «формального методу» має розумітись умовно, оскільки для нього є характерним не «формалізм» як апологетика форми і не «методологія» як стала наукова система, а в першу чергу намагання створити самостійну науку про художне слово на основі специфічних властивостей літературного матеріалу. Формалістам було потрібне теоретичне та історичне усвідомлення фактів словесного мистецтва як такого.

Залишивши в стороні цілий ряд загальних проблем, формалісти зосередились на конкретних проблемах мистецтвознавства. На перший план вийшло питання художньої форми та її еволюції, а звідси - цілий ряд конкретних теоретичних та історичних питань.

Формалісти встановили, що відношення між різними частинами твору можуть будуватись за принципами паралелізму або опозиції, однак, структура його внутрішніх відносин залишається незмінною. Головною категорією вивчення стає форма як центральне поняття в побудові та дослідженні художнього твору. Першим прикладом такого дослідження є стаття Б. Ейхенбаума «Як зроблена «Шинель» Гоголя», в якій ставиться проблема розуміння конструкції художнього твору. Це перша концептуальна робота формального або, як зазначав Ейхенбаум, морфологічного напряму. Вона присвячена композиції новели, яка, на його думку, залежить від особливої розповідної манери автора, що може бути організуючим початком твору або лише формальним зв'язком між подіями. На думку Ейхенбаума, основу композиції твору Гоголя складає не сюжет, який має лише зовнішнє значення, а мовна гра, тобто «справжня динаміка, а тим самим і композиція його речей в побудові сказу, в грі мови» [5, с.311]. Отже, ототожнення певних частин твору із змістом авторської душі $є$ хибним для науки шляхом. До того ж одна із особливостей художньої діяльності полягає в тому, що художник завжди знаходиться під впливом досвіду інших поколінь митців, сформованого в темах та ідеях мистецтва та вираженого в певних жанрах та стилях. Тому зміст твору не може не втілити в собі ті компоненти, що закріплені у вже набутих засобах вираження.

На відміну від традиційного протиставлення форми та змісту в роботах формалістів поняття форми виступає в новому значенні - не як оболонка, а як змістовна сама по собі повнота твору. Така позиція не мала на меті продемонструвати перевагу форми над змістом, а намагалась представити сам зміст в якості форми, зафіксованої в системі мови. Згідно до цього форма не передає деякий усталений зміст, а 
сприяє виробленню власного, самостійного погляду та формуванню змістовної насиченості твору. Конструктивне значення форми полягає в її спрямованості як на зовнішнє оформлення тексту в його структурно-фактурній речовості, так і на діяльність сприйняття даного тексту.

Схожа тенденція спостерігається в роботах Московського лінгвістичного гуртка на чолі з Р. Якобсоном, де головним об'єктом дослідження стає технічна конструкція художнього твору, тобто його структура у вигляді художньої форми. Літературний твір набуває статусу самостійної одиниці. Празький лінгвістичний гурток (Я. Мукаржовський, Н. Трубецькой, Г. Вінокур та ін.), формуючи концептуальний апарат структурного аналізу тексту, наполягає на тому, що в центрі дослідження має бути твір, вільний від усього, що пов'язує його з іншими явищами. Літературний твір, що розглядається в якості функціональної структури, створюється внаслідок «відчуження» від світу: мистецтво руйнує традиційні знакові системи, привертаючи увагу до матеріального втілення мови.

Оскільки формалісти виказали думку про те, що літературний твір не $є$ відображенням зовнішньої реальності, а $є$ функцією буденної мови, то художній твір не потребує дійсності, що виступає необхідною висхідною причиною по відношенню до «реальності твору». Орієнтація на погляди В.Шкловського на мистецтво як на сукупність прийомів вказує на фізичну незавершеність тексту і забезпечує розуміння художньої структури як феномену, що зумовлює «відчуття речі як бачення, а не впізнання» [4, с. 15]. В акті сприйняття реципієнт виступає не як суб'єкт, а як діяльність. Твір як сукупність прийомів не розпадається на окремі фрагменти, оскільки його об'єднуючий центр знаходиться за межами самого твору. Зовнішньюю умовою цілісності тексту виступає сприйняття читачем структурно-технічної основи твору, що надається автором в якості прийому для подальшого со-творіння речі. Отже, в творі не копіюється зовнішня реальність, а річ конструюється за допомогою відстороненого бачення, в процесі якого розкривається сама сутність речі, її внутрішні потенції та інобуття.

Структурний підхід у певній мірі $є$ продовженням формального методу, хоча поняття форми замінюється більш широким поняттям структури. В структуралізмі на перший план виходить проблема співвідношення структури та твору, де структура, займаючи домінуюче положення, представляє собою абстракцію, а твір виступає матеріалізацією структурних законів тексту. Об'єктом дослідження в структуралізмі стає текст в широкому значенні, під ним може розумітись як художній твір, так і все те, що виступає результатом людської діяль- 
ності. Теоретична програма структуралістів передбачала дослідження законів цілісності художнього твору, найбільш загальних принципів його організації, співвідношення різних компонентів та рівнів.

Оскільки структуралізм відштовхувався від законів лінгвістичного аналізу тексту, в основу аналізу літературних творів було покладено модель лінгвістики. Текст виступає як певний рід висловлювань, що можуть бути класифіковані за типовими ознаками. Структуралісти запропонували розгляд літературного тексту поза контекстом світової літератури та творчістю письменника, тому художній твір постає як окрема самостійна одиниця. Справжній смисл твору слід відшукувати в його структурі, що є самодостатнім цілим, яке не потребує ні автора, ні читача. На думку Р.Барта, структурний аналіз має здійснюватись в рамках самого твору та не виходити за його межі. На відміну від художнього твору текст не є цілісним організмом, його можна подрібнювати на частини, а також «можна читати, не приймаючи в розрахунок волю його батька» $[1$, с. 419].

Звертаючись до художньої практики, структуралізм тлумачить взаємозв'язок всіх художньо-виразних елементів твору як особливим чином організовану систему. Наполягаючи на існуванні сталого зв'язку між елементами, Р.Барт зазначає, що саме цей взаємозв'язок виступає глибинним підгрунтям художнього твору, на тлі якого розгортається сюжет. Художній твір як текст можна досліджувати як на рівні його макроструктури, тобто смислових зв'язків між частинами тексту та окремими реченнями, так і на рівні мікроструктури, тобто, досліджуючи правила поєднання елементів всередині речення. Ілюструючи свій підхід, Барт аналізує новелу Бальзака «Сарразін», виокремлюючи в ній безліч значущих елементів. Аналіз зв'язків між ними дає йому підстави вважати новелу будовою із складним та неоднозначним змістом. Однак, саме за такий метод аналізу найчастіше критикують структурний підхід, оскільки втрачається цілісність значення всього твору. На нашу думку, не можна казати, що дослідження окремих складових частин не дозволяє скласти цілісне уявлення про смисл тексту, оскільки таке дослідження проводиться в сукупності і не зосереджується на аналізі одного окремого елемента. В результаті поєднання складових елементів твору, їх внутрішнього відношення народжується значення тексту, яке, в свою чергу, виступає умовою єдності тексту, його цілісності.

Поняття структури є основним у теоретичних поглядах Ю. Лотмана. Не дивлячись на те, що з середини 70-х років ХХ століття Лотман відходить від структурного вивчення об'єктів культури, в методологі- 
чному плані його наукову позицію можна окреслити як структурносеміотичну. В основу структурного підходу покладено відмову від аналізу твору на основі механічного перерахування його ознак. На думку вченого, художній твір - це не сума ознак, а структура, тому завдання дослідника має полягати в конструюванні моделі зв'язків в структурі твору.

В цьому відношенні перевага структурного підходу полягає в розгляді художнього тексту як цілісності, де акцент робиться не на окремі елементи, а на їх співвіднесеність з іншими елементами структури та зовнішнім світом. Згідно структурного підходу, вирвані з контексту, окремі елементи не мають значення як складові цілісності твору. На думку Лотмана, сутність кожного елементу може бути розкрита не через опис його ізольованої природи, а в результаті дослідження того, що йому протиставлено. Завданням дослідника, за Лотманом, стає виявлення структурних рівнів об'єкту та побудова його наукової моделі. В роботі «Структура художнього тексту» автор наводить ряд вагомих аргументів на користь необхідності структурного іманентного розгляду художнього тексту, взятого як окреме, закінчене та внутрішньо самостійне ціле. На думку вченого, такий підхід до тексту є необхідним початковим етапом його вивчення. Оскільки художній текст фіксується особливою мовою- мовою мистецтва, внутрішнє вивчення цієї мови стає закономірним шляхом для розуміння змісту тексту. Вчений пише, що «іманентне вивчення мови - шлях (і суттєвий) до змісту того, про що там написано» [2, с. 47], тому в центрі уваги постає проблема співвіднесення мови художнього тексту з його значенням.

В своїй подальшій роботі тартуський вчений відходить від розуміння структури як системи опозиційних відношень значимих елементів та побудови на цій основі логіки іманентного аналізу художнього тексту. В пізніх роботах поступово відбувається ототожнення структури та значення, що суттєво зміщує методологію вченого в семіотичному напрямку, а також сприяє відходу від чисто структурного аналізу. Семіотика, за визначенням Лотмана, постає як метод гуманітарних наук, що визначений не природою об'єкта дослідження, а способом його аналізу. Однак, онтологізуючи знакову природу явищ культури, в центр своєї концептуальної системи дослідник поклав не знак, структуру або бінарні опозиції, а текст. Художній твір в його теорії виступає текстом найвищої категорії складності.

3 точки зору семіотики текст-це система, в якій значення задаються контекстом та керуються схожістю та опозицією. Літературний твір постійно трансформує прості значення та встановлює нові шля- 
хом зіставлення різних частин тексту. Кожне слово в тексті входить у ряд формальних структур, кожен знак бере участь у декількох різних системах. На основі цього Лотман визначає художній текст як результат зіткнення різних кодів, або як систему взаємних перекодувань. Цей підхід дозволяє стверджувати, що, з точки зору семіотики, художній твір потребує дослідження складних взаємозв'язків між словами, частинами речення або між окремими реченнями в тексті. Окрім того, семіотичний аналіз здатен здійснити дослідження великих частин тексту та виявити їх взаємозв'язок, що дозволяє більш точно визначити тему або форму твору.

Виходячи $з$ того, що художній твір є текстом підвищеної складності, зведення змісту твору до його основної ідеї, до того, що намагався сказати автор, а також окреме вивчення форми твору та його змісту розуміються вченим як спрощення художньої структури, що призведе до руйнування iï єдності. На думку Лотмана, «ідея в мистецтві-це завжди модель, оскільки вона відтворює образ дійсності. Таким чином, поза структурою художня ідея немислима. Дуалізм форми та змісту має бути замінений поняттям ідеї, що реалізує себе в адекватній структурі і не існує поза цією структурою» [2, с. 19]. Відповідно до цього в творі не може бути формальних елементів, оскільки художній текст характеризується складно побудованим смислом, всі його елементи $є$ смисловими. Тому в структурі художнього твору не можна віднайти нічого випадкового, всі його формальні елементи навантажені значеннями.

Однією з фундаментальних характеристик твору виступає його багатозначність. Зашифровані за допомогою різних кодів елементи тексту вступають у складні ігрові взаємовідносини один з одним та 3 пам'яттю реципієнтів, кожного разу продукуючи новий смисл. Як і інші тексти, тексти мистецтва здатні функціонувати, лише будучи зануреними у семіотичне середовище. Для реалізації закладених в ньому можливостей художньому тексту необхідно вступати у взаємодію з аудиторією, звідси наголос на ідеї діалогічності мистецтва, широко розвиненої в роботах М.Бахтіна. Для різної аудиторії твори мистецтва розкриваються по-різному, залежно від рівня розуміння кожного конкретного глядача, слухача, читача.

Наведена вище думка про те, що значенням художнього твору є його смисл, підкріплює орієнтацію лінгвістичного структуралізму на тезу, згідно з якою художній твір вже не є безпосереднім відображенням дійсності, а $є$ особливим типом висловлювання, спрямованим на вираження самого себе. В статті «Семіотика літератури» Ц. Тодоров, 
підкреслюючи таке розуміння літератури, зазначив, що складові літературного дискурсу не $\epsilon$ ні істинними, ні хибними, але створюють уявлення про неіснуючу реальність та виявляють «зосередженість уваги на повідомленні заради нього самого» [3, с.351]. Художня література не $є$ відображенням реальності, оскільки це функція буденної мови, а $є$ відображенням мовної діяльності, властивій певній національній мовній культурі, до якої належить автор. Завдяки цьому роман Пушкіна став взірцем російської мовної культури, закріпленої у певних смислах та збагаченої новими смислами, запозиченими з досвіду західної літератури. Семіотичний підхід в літературі зосереджується на реальності існування певної події в творі, матеріалізованої за допомогою знаків, що знаходяться в прямій залежності від контексту твору.

Отже, ми можемо зробити висновок, що на структурно-лінгвістичному рівні більша увага приділяється формальному методу аналізу літературного твору, натомість на рівні структурно-семіотичному робиться акцент на необхідності виділення різних площин твору, виявленні його знакових рівнів та встановленні їх взаємодії на основі взаємного перекладу. В структуралізмі художній твір виступає як особливого роду впорядкованість, що гармонійно поєднує його внутрішню та зовнішню сутності, знімаючи різке протиставлення форми та змісту, що має принципове значення для дослідження онтологічного статусу художнього твору.

Перспективними моментами структурно-семіотичного аналізу $є$ орієнтація на художній твір як на текст, наповнений багатозначними смислами, та відмова від психологізму та суб'єктивізму в мистецтві. В цьому відношенні спроба концептуального обгрунтування формалістичної теорії як методологічного підгрунтя структуралізму та висвітлення його специфічних наукових принципів на прикладі літературного матеріалу дає підстави вважати іманентний аналіз художнього твору одним із важливих підходів до вивчення творів мистецтва. Семіотичний спосіб співставлення окремих елементів твору із знаковими системами в синхронічному та діахронічному плані може допомогти в поясненні різних тлумачень художнього твору. Використання семіотичного методу також дозволяє оцінити можливості адекватного перекладу літературного твору на мову інших видів мистецтва та є перспективним напрямом для подальших досліджень. На нашу думку, переваги семіотичного методу не можна заперечити, оскільки він дозволяє краще побачити різні елементи, рівні твору. I хоча він не є достатнім для тотального художнього аналізу, його застосування, беззаперечно, $\epsilon$ перспективним для дослідження творів різних видів мистецтва. 


\section{1 Бібліографія}

[1] Барт Р. Избранные работы: Семиотика: Поэтика: Пер. с фр. / Сост., общ. ред. и вступ. ст. Г.К. Косикова. - М.: Прогресс, 1989.

[2] Лотман Ю.М. Структура художественного текста. - М.: Искусство, 1970.

[3] Тодоров Ц. Семиотика литературы // Семиотика. - М.: Радуга, 1983. - C. 355-370.

[4] ШКловский В.Б. Искусство как прием // О теории прозы.-М: Советский писатель, 1983. - С. 9-25.

[5] Эйхенбаум Б.М. Как сделана «Шинель» Гоголя // О прозе. - Ленинград: Художественная литература, 1969. - С. 306-327. 